[ノート]

\title{
イソペンタンの気相均一酸化反応による各種含酸素 化合物の生成経路
}

\author{
長田 秀夫* ${ }^{\dagger 1}$, , 田代 靜香, 岸田 昌浩, 若林 勝彦 \\ 九州大学大学院工学研究院物質プロセス工学専攻化学プロセス教室, 812-8581 福岡市東区箱崎 6-10-1
}

(2001 年 3 月 21 日受理)

\begin{abstract}
イソペンタンの気相酸化反応を無触媒条件下で行った。その結果，いずれの反応温度においても主生成物は含酸素 化合物（3-メチルテトラヒドロフラン，2-プロピルオキシラン，2-エチル-2-メチルオキシラン，2,2,3-トリメチルオキ シラン，アセトンおよびアセトアルデヒド）抽びイソペンテン類（2-メチル-1-ブテン，2-メチル-2-ブテンおよび 3-メチル-1-ブテン）であった。生成物選択率の反応ガス滞留時間依存性を調べたところ，イソペンタンの気相酸化反 応による含酸素化合物の生成は, イソペンタンから生成したイソペンテン類への酸素の付加反応によると考えた。さ らに, イソペンテン類の気相酸化反応の結果から，3-メチルテトラヒドロフランおよび 2-プロピルオキシランは 3-メ チル-1-ブテンを経由し，2,2,3-トリメチルオキシランおよびアセトンは2-メチル-2-ブテンを経由し，2-エチル-2-メチ ルオキシランは2-メチル-1-ブテンを経由して生成すると考えた。
\end{abstract}

\section{1. 緒言}

ペンタン類（ペンタンおよびイソペンタン）を他の有用化合 物へ接触的に転化する研究例は他の低級炭化水素に比べて少な ( (1)-5)。Centi ら ${ }^{1), 2)}$ は, ペンタンの気相酸化反応により無水マ レイン酸 (炭素数が減少) へ変換する研究を行っている。ある いは, 岩崎らはイソペンタンをイソプレンへ接触酸化的に転化

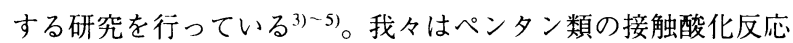
による有用含酸素化合物合成の前段階として, ペンタン類の気 相酸化反応によりどのような化合物が生成するか，またそれら の生成物はどのような経路で生成するか, などの検討を行って いる。ペンタンからの2-メチルテトラヒドロフランの生成は 反応時間の短いところではペンタンの酸化によるペンチルパー オキサイドを経て進行し, 反応時間が長くなるとペンタンの酸 化脱水素により生成したペンテン類の酸化を経て進行すること を報告した6)。

ペンタンに比ベイソペンタンは酸化脱水素により天然ゴムお よび合成ゴム等の原料となるイソプレンを生成することから， ペンタンの酸化よりもより重要と考えられる。接触酸化反応を 研究する前段階として気相酸化反応について詳細な検討を行う ことは, 接触酸化反応における触媒の寄与を明確にすることが できる。あるいは気相酸化反応で有用な生成物が得られれば, 触媒等の利用によりさらに有用化合物収量を増加させることが できるという点からも意義深いものである。しかし, イソペン タンの気相酸化を扱った研究の報告はほとんどない3)。そこで, 本研究ではイソペンタンの気相酸化反応を行い, 本反応により 生成した含酸素化合物の生成経路についての検討を行った。

* 連絡先

†1) (現在) 佐世保工業高等専門学校物質工学科, 857-1193 長崎県佐世保市沖新町 1-1

\section{2. 実験方法}

反応は通常の常圧流通式反応装置で行った。反応管には内径 $8 \mathrm{~mm} \phi$, 長さ $240 \mathrm{~mm}$ のパイレックス製のガラス管を用いた。 設定温度に対して反応管内の温度変化が $\pm 2.0 \mathrm{~K}$ 以内の部分が $120 \mathrm{~mm}$ あり，この部分からずれると反応管内の温度は急速に 低下した。そこで, この $\pm 2.0 \mathrm{~K}$ 以内の部分の体積 $\left(\right.$ 約 $\left.6 \mathrm{~cm}^{3}\right)$ を反応器の体積とした。

反応温度は $573 \sim 773 \mathrm{~K}$ まで変化させだ。反応ガスの滞留時 間は $\alpha$-アルミナを充てんすることにより制御した。イソペン タンおよびイソペンテンは飽和器を通して供給し同伴ガスとし て窒素を用いた。酸素供給は純酸素ガスを用いて行い, 窒素に より所定の分圧に調整した。反応ガス組成は炭化水素分圧

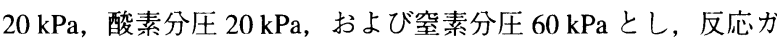
ス流速は $60 \mathrm{~cm}^{3} / \mathrm{min}$ とした。反応ガスおよび生成ガスの定量 分析にはガスクロマトグラフ（FID 型 2 台および TCD 型 1 台） を用い，含酸素化合物の分析は $373 \mathrm{~K}$ に保持したガスサンプラ 一から直接オンラインでガスクロマトグラフに導入して行っ た。酸素, 窒素および一酸化炭素の分析にはMS-5A を，二酸 化炭素の分析には Porapak-QS を，炭化水素類の分析には VZ10 を, 含酸素化合物の分析にはPEG6000を充てん剂として用 いた。生成物の同定はガスクロマトグラフ-質量分析装置によ り行った。

転化率，収率，および選択率は以下の式から求めた。 転化率 $(\%)=1-\frac{\text { 反応物のモル数（出口） }}{\text { 反応物のモル数 }(\text { 入口 })} \times 100$ 収率 $(\%)=\frac{\begin{array}{l}\text { モル生数 }(\text { 出口 }) \times \text { 物成物の } \\ \text { 炭素数 }\end{array}}{\text { モ゚ンタンの }} \times 100$ 選択率 $(\%)=$ (収率 / 転化率 $) \times 100$ 


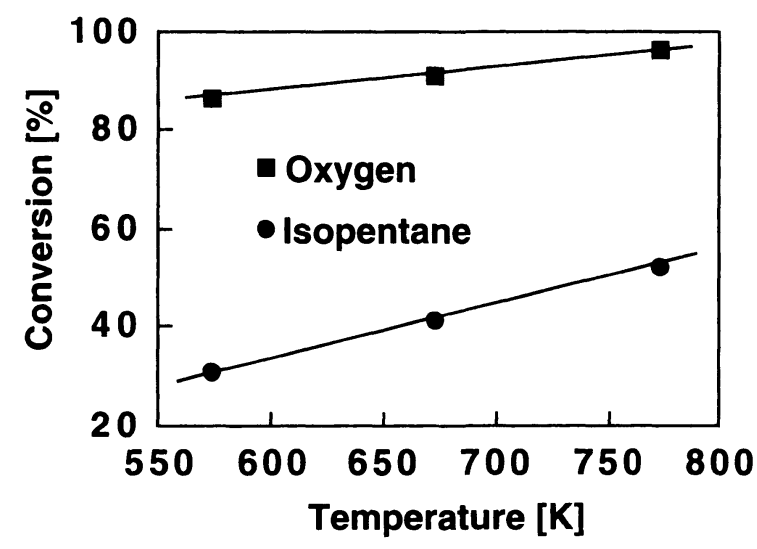

Temperature, $673 \mathrm{~K}$; feed gas, $20 \%$ isopentane-20\% oxygen-60\% nitrogen; feed gas rate, $60 \mathrm{ml} / \mathrm{min}$; pressure, $0.1 \mathrm{MPa}$; residence time, $55 \mathrm{~s}$.

Fig. 1 Relationship between Conversion and Temperature in the Vapor-phase Oxidation of Isopentane

\section{3. 実験 結果}

\section{1. イソペンタンの反応}

酸素分圧が $20 \mathrm{kPa}$ 以下の炭化水素リッチの反応条件下でイ ソペンタンの酸化反応を行った。含酸素化合物として3-メチ ルテトラヒドロフラン (3-MeTHF), アセトン, アセトアルデ ヒド，2-エチル-2-メチルオキシラン，2-プロピルオキシランお よび 2,2,3-トリメチルオキシランが主に生成し, 炭化水素とし てイソペンテン類, ブテン類, プロピレン, およびエチレンが 生成し，プロパン，エタン等のアルカン類はほとんど生成しな かった。完全酸化生成物である酸化炭素（二酸化炭素および一 酸化炭素) の生成も認められた。また, 酸素が存在しないイソ ペンタンー窒素の混合物を反応管に流通させても, 全く反応が 起こらなかった。これらのことから，イソペンタンの反応には 酸素が必要であることがわかった。

\subsection{1. 反応温度依存性}

反応温度を $573 \sim 773 \mathrm{~K}$ に変化させてイソペンタンの気相酸 化反応を行った。イソペンタンおよび酸素の転化率の温度依存 性をFig. 1 に示す。ペンタンの気相酸化反応の場合, 反応温 度の上昇とともに酸素転化率が隇少(た6)。これに対してイソ ペンタンの気相酸化反応では反応温度が上昇するのに伴ってイ ソペンタンおよび酸素の転化率とも増加した。後で述べるよう に, イソペンタンの場合は反応温度によらず主生成物は含酸素 化合物であり，反応温度が上昇すると含酸素化合物の収率が増 加していることから酸素の消費量が増加したと考えられる。一 方, ペンタンの場合は, 反応温度の上昇に伴って主生成物が酸 素消費量の多い含酸素化合物から酸素消費量の少ない分解生成 物へと变化した6)ことによると考えられる。次に，生成物選択 率の温度依存性を Fig. 2 に示す。主生成物は反応温度によら ず含酸素化合物であった。反応温度の上昇とともに，含酸素化 合物の選択率はわずかながら隇少し，これに相反してその分炭 化水素の選択率が増加した。一方, 酸化炭素（二酸化炭素およ

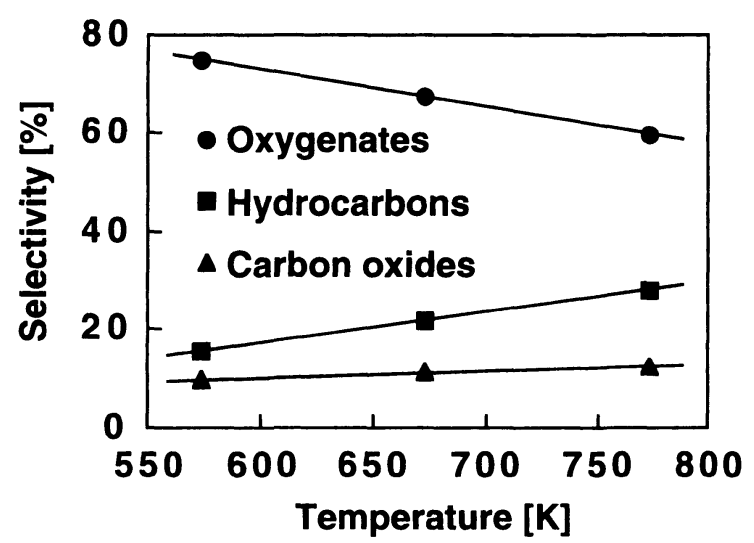

The reaction conditions are the same as those in Fig. 1.

Fig. 2 Relationship between Product Selectivity and Temperature in the Vapor-phase Oxidation of Isopentane

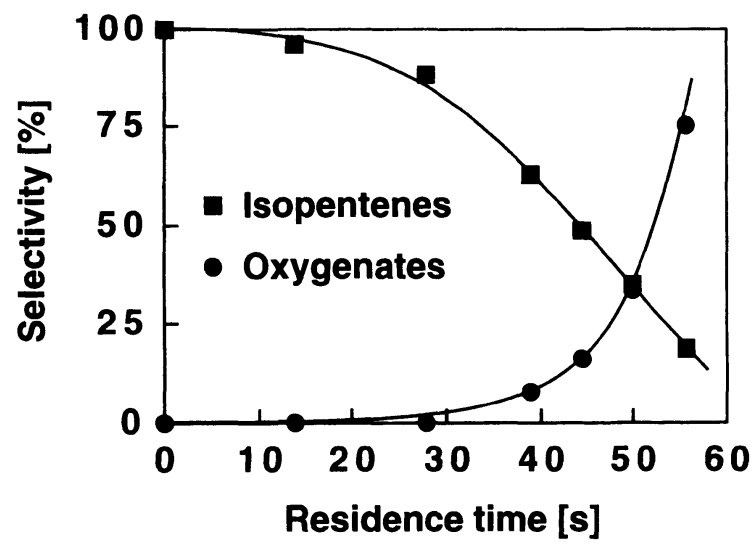

Temperature, $673 \mathrm{~K}$; feed gas, $20 \%$ isopentane-20\% oxygen- $60 \%$ nitrogen; feed gas rate, $60 \mathrm{ml} / \mathrm{min}$; pressure, $0.1 \mathrm{MPa}$.

Fig. 3 Relationship of Yields of Oxygenated Compounds and Isopentenes with Residence Time in the Vapor-phase Oxidation of Isopentane

び一酸化炭素）の選択率は若干増加する傾向が認められたもの の, 他の生成物に比べその変化量は小さかった。

\subsection{2. 滞留時間依存性}

反応管に $\alpha$-アルミナを充てんし, 反応ガスの高温部での滞 留時間を変化させてイソペンタンの気相酸化反応を行った。イ ソペンテン類および含酸素化合物の選択率の滞留時間による変 化を Fig. 3 に示す。含酸素化合物は滞留時間が比較的短い, つまり反応初期には認められず, 生成物は炭化水素類のみであ った。この結果は岩崎ら ${ }^{3)}$ の結果とよく符合する。生成した炭 化水素類の中でイソペンテン類の選択率は滞留時間の増加とと もに隇少し, 滞留時間が長いところではエチレン, プロピレン およびブテン類の生成が認められた。一方, 含酸素化合物の生 成は, 滞留時間が $30 \mathrm{~s}$ 程度まではほとんど認められなかった 
Table 1 Selectivities of Oxygenated Compounds in the Vaporphase Oxidation of Isopentane and Isopentene

\begin{tabular}{lrrrrr}
\hline \multirow{2}{*}{ Reactant } & \multicolumn{5}{c}{ Selectivity [\%] } \\
\cline { 2 - 6 } & 3-MeTHF & Acetone & Prod. A & Prod. B & Prod. C \\
\hline Isopentane & 13.6 & 13.3 & 9.5 & 6.7 & 7.3 \\
Isopentene (1) & 17.2 & 4.5 & 1.2 & 48.3 & 0.9 \\
Isopentene (2) & 1.9 & 51.3 & 29.4 & 0.0 & 1.9 \\
Isopentene (3) & 50.9 & 2.2 & 0.0 & 0.0 & 22.5 \\
\hline
\end{tabular}

Isopentene (1), 2-methyl-1-butene; Isopentene (2), 2-methyl-2butene; Isopentene (3), 3-methyl-1-butene.

3-MeTHF, 3-methyltetrahydrofuran; Prod. A, 2,2,3-trimethyloxirane; Prod. B, 2-ethyl-2-methyloxirane; Prod. C, 2-propyloxirane

Temperature, $673 \mathrm{~K}$; feed gas, $20 \%$ hydrocarbon- $20 \%$ oxygen$60 \%$ nitrogen; feed gas rate, $60 \mathrm{~m} / / \mathrm{min}$; pressure, $0.1 \mathrm{MPa}$; residence time, $55 \mathrm{~s}$.

が，滞留時間が $30 \mathrm{~s}$ 以上になると滞留時間の増加とともに急 激に選択率が上昇した。含酸素化合物選択率を滞留時間ゼロに 外挿すると接線の傾き（生成速度に対応する）がゼロであるこ と，および滞留時間が短い，つまり反応初期においては生成物 は炭化水素類のみであることから，含酸素化合物はペンテン類 を経由して生成することが示唆された。含酸素生成物個々の場 合 (3-メチルテトラヒドロフラン (3-MeTHF)，アセトン，ア セトアルデヒド, 2-エチル-2-メチルオキシラン，2-プロピルオ キシランおよび 2,2,3-トリメチルオキシラン) についても同様 の結果が得られた。

ペンタンの気相酸化反応においてはペンタンから直接含酸素 化合物が生成する経路が存在しだ) が，先にも述べたように， イソペンタン酸化では含酸素化合物の直接生成経路が存在しな かった。イソペンタンから最初に生成すると考えられるのは 2-メチル-2-ブチルラジカルであり，さらに水素ラジカルの脱離 が起こるとイソペンテン類となる。一方，この 2-メチル-2-ブ チルラジカルに酸素が付加すると 2-メチル-2-ブチルパーオキ シラジカルが生成し，これが含酸素化合物へ変化する直接の経 路となると考えられる。そこで, 2-メチル-2-ブチルラジカルと 2-メチル-2-ブチルパーオキシラジカルの安定性を比較すると, 2-メチル-2-ブチルラジカルの方がはるかに安定であると考えら れる。したがって，イソペンタンにおいては含酸素化合物の直 接生成経路が存在しなかったのは, ラジカルへの酸素付加より も酸化脱水素の方が優勢となるためであると考えられる。

\section{2. イソペンタンとイソペンテン類の反応生成物の比較}

反応温度 $673 \mathrm{~K}$ で $20 \%$ イソペンテン $-20 \%$ 酸素- $60 \%$ 窒素 の反応ガスを用いてイソペンテン類（2-メチル-1-ブテン， 2-メ チル-2-ブテンおよび3-メチル-1-ブテン）の気相酸化反応を行 った。イソペンタンおよびイソペンテン類の含酸素生成物につ いて比較した結果を Table 1 に示す。イソペンテン類の生成物 については，3-メチル-1-ブテンからは 3-MeTHF および2-プロ ピルオキシランが, 2-メチル-1-ブテンからは2-エチル-2-メチ ルオキシランが比較的高い収率で生成し，主な含酸素生成物は いずれも炭素数が 5 のものであり，炭素-炭素結合の切断はあ まり起こらなかった。一方，2-メチル-2-ブテンからは，Ray お よび Waddington の結果 ${ }^{7)}$ と同様に，2,2,3-トリメチルオキシラ

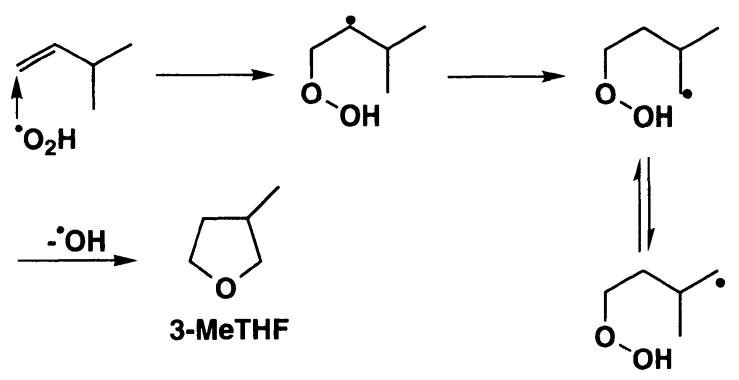

Scheme 1 Formation Pathway of 3-Methyltetrahydrofuran from 3-Methyl-1-butene

ン，アセトンおよびアセトアルデヒドが比較的高い収率で生成 し，炭素一炭素結合が切断した生成物も比較的多く認められた。

\section{4. 考察}

側鎖状の飽和炭化水素類の気相酸化反応についての研究例は 直鎖状のものに比べて少ないものの，本研究で得られた結果と 既に報告されている直鎖状の炭化水素類の結果を基にして，イ ソペンタンの含酸素化合物の生成経路について考察した。まず, イソペンタンからイソペンテン類の生成については, 先にも述 ベたように，酸素が存在した系ではイソペンテン類の生成が認 められ，酸素が存在しない系では反応が起こらなかったことか ら, イソペンテン類はイソペンタンの酸化脱水素により生成し たものと考えられる。イソペンタンからイソペンテン類の生成 経路はペンチルパーオキシラジカルの分解8),99，あるいは酸素 によるペンチルラジカルからの水素ラジカルの引き抜き8),10) と 考えられる。次に，イソペンテン類からの主要な含酸素化合物 の生成経路について考察する。

\subsection{3-メチル-1-ブテンの酸化反応}

Scheme 1 に3-メチル-1-ブテンからの3-メチルテトラヒドロ フランの生成経路を示す。 2 重結合を有するアルケンの酸素付

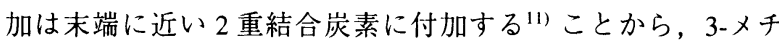
ル-1-ブテンはその末端の 2 重結合炭素に過酸化水酸基ラジカ ル等の攻撃を受け $\gamma$ 位にラジカルを持つ中間体を生成し，これ がラジカル移行反応により末端にラジカルを持つ中間体へ転移 する。この中間体は 2 力所の末端炭素にラジカルが非局在化し 安定化する。この中間体から炭素-酸素結合の生成と水酸基ラ ジカルの脱離によって3-メチルテトラヒドロフランが生成す ると考えられる。

Scheme 2 に3-メチル-1-ブテンからの 2-プロピルオキシラン の生成経路を示す。Scheme 1 と同様に，3-メチル-1-ブテンは その末端の 2 重結合炭素に過酸化水酸基ラジカル等の攻撃を受 $\left({ }^{11)} ， \gamma\right.$ 位にラジカルを持つ中間体を生成する。ラジカル移行 反応が起こる前に炭素-酸素結合の生成と水酸基ラジカルの脱 離が起こると，2-プロピルオキシランが生成すると考えられる。

\subsection{2-メチル-2-ブテンの酸化反応}

Scheme 3 に2-メチル-2-ブテンからの 2,2,3-トリメチルオキ シランの生成経路を示す。2-メチル-2-ブテンへの過酸化水酸基 ラジカル等の攻撃は 3 級の炭素にラジカルができるように起こ

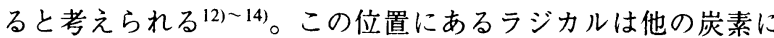




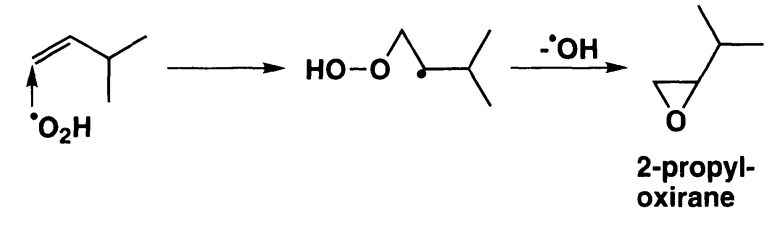

Scheme 2 Formation Pathway of 2-Propyloxirane from 3Methyl-1-butene

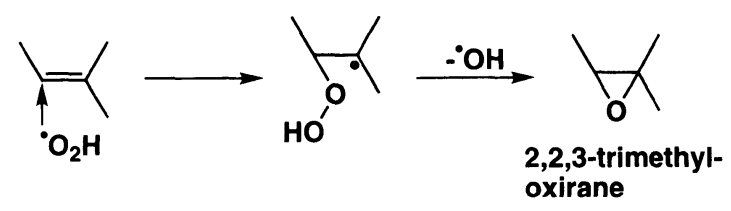

Scheme 3 Formation Pathway of 2,2,3-Trimethyloxirane from 2-Methyl-2-butene

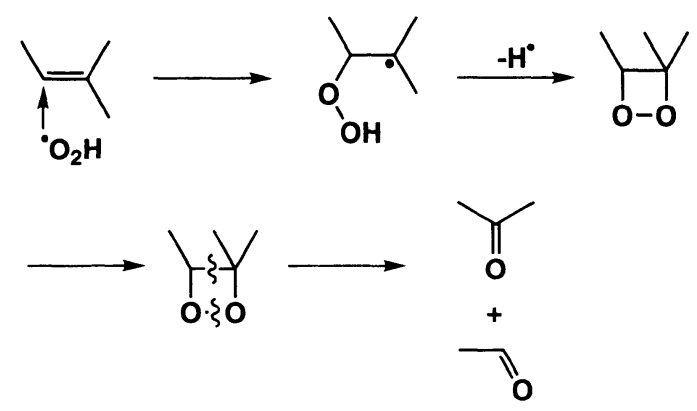

Scheme 4 Formation Pathway of Acetone from 2-Methyl-2butene

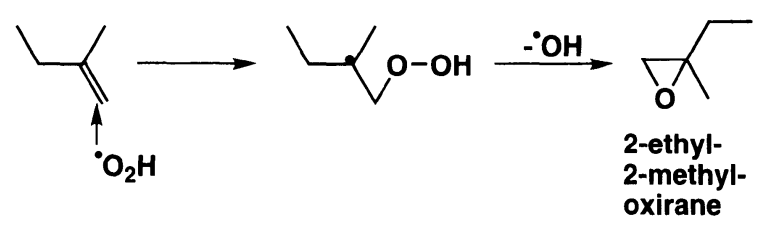

Scheme 5 Formation Pathway of 2-Ethyl-2-methyloxirane from 2-Methyl-1-butene

素上のラジカルよりも安定であり, 他の炭素へのラジカルの移 動はあまり起こらないため,この炭素ラジカルと酸素による炭 素-酸素結合の生成と水酸基ラジカルの脱離により 2-エチル-2メチルオキシランが生成すると考えられる。

\section{5. 結言}

イソペンタンおよびイソペンテン類（2-メチル-1-ブテン，2メチル-2-ブテンおよび3-メチル-1-ブテン）の気相酸化反応を 無触媒条件下で行ったところ，以下のことがわかった。

（1）イソペンタンの気相酸化反応では，ペンタンの場合とは異 なり, 反応温度の上昇とともに酸素転化率は増加した。この差 異は両反応の高温における生成物分布の違いから説明できた。

（2）イソペンタンからの含酸素化合物の生成は，ペンタンの場 合のように直接酸化が起こって生成する経路がなく, イソペン テン類を経由する経路のみであった。これは, 最初に生成する と考えられるラジカルの安定性から説明できた。

（3）イソペンタンから生成する主要含酸素化合物の生成経路に ついては，3-メチルテトラヒドロフランおよび2-プロピルオキ シランは3-メチル-1-ブテンを経由して，2,2,3-トリメチルオキ シランおよびアセトンは2-メチル-2-ブテンを経由して，2-エ チル-2-メチルオキシランは2-メチル-1-ブテンを経由して生成 するモデルを提案した。

\section{References}

1) Centi, G., Trifiro, F., Catal. Today, 3, 151 (1988).

2) Centi, G., Trifiro, F., "Proc. 1st Tokyo Confer. Adv. Catal. Sci. Technol., Tokyo, 1990," eds. by Yoshida, S. et al., Kodansha, Tokyo (1991), p.225.

3) Iwasaki, M., Furuya, H., Morinaga, M., Sekiyu Gakkaishi, 35, (3), 137 (1992).

4) Iwasaki, M., Furuya, H., Morinaga, M., Sekiyu Gakkaishi, 35, (3), 145 (1992).

5) Iwasaki, M., Furuya, H., Morinaga, M., Sekiyu Gakkaishi, 35, (3), 154 (1992).

6) Nagata, H., Yamamoto, N., Takiyama, Y., Kishida, M., Wakabayashi, K., Sekiyu Gakkaishi, 38, (3), 203 (1995).

7) Ray, D. J. M., Waddington, D. J., Combust. Flame, 21, 327 (1973).

8) Chung, Y.-S., Sandler, S., Combust. Flame, 6, 295 (1962); 7, 339 (1963).

9) Tipper, C. F. H., Quart. Rev. Chem. Soc., 11, 313 (1957).

10) Satterfield, C. N., Reid, R. C., J. Phys. Chem., 59, 283 (1955).

11) Berry, T., Cullis, C. F., Trimm, D. L., Proc. R. Soc. Lond. A., 316, 377 (1970).

12) Baldwin, R. R., Everett, C. J., Hopkins, D. E., Walker, R. W., Am. Chem. Soc., Adv. Chem. Ser., 76, 124 (1968).

13) Baker, R. R., Baldwin, R. R., Walker, R. W., 13th Int. Symp. Combust., Combust. Soc., Pittsburgh, 1971, p.291.

級の炭素にラジカルが生成するように起こるため末端の炭素に

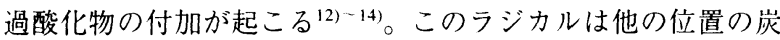


14) Baldwin, R. R., Hisham, M. W. M., Walker, R. W., J. Chem. Soc., Faraday Trans. 1, 78, 1615 (1982).

\title{
Summary
}

\section{Formation Pathway of Various Oxygenated Compounds for the Homogeneous Oxidation of Isopentane in the Vapor Phase}

\author{
Hideo NAGATA ${ }^{\dagger 1}$, Shizuka TASHIRo, Masahiro KISHIDA, and Katsuhiko WAKABAYASHI \\ Chemical Engineering Gr., Dept. of Materials Process Engineering, Graduate School of Engineering, Kyushu University, \\ 6-10-1 Hakozaki, Higashi-ku, Fukuoka 812-8581, JAPAN \\ ${ }^{\dagger 1)}$ (Present) Dept. of Chemical and Biological Engineering, Sasebo National College of Technology, \\ 1-1 Okishin-machi, Sasebo, Nagasaki 857-1193, JAPAN
}

The homogeneous oxidation of isopentane was investigated in the vapor phase. The main products were oxygenated compounds (3-methyltetrahydrofuran, 2-propyloxirane, 2ethyl-2-methyloxirane, 2,2,3-trimethyloxirane, acetone and acetaldehyde) and isopentenes. The yields of oxygenated compounds and isopentenes depended on the residence time, indicating that the oxygenated compounds formed through isopentenes from isopentane. It is concluded from the results of the vapor-phase oxidation of isopentenes (3-methyl1-butene, 2-methyl-2-butene and 2-methyl-1-butene) that 3methyltetrahydrofuran and 2-propyloxirane might be formed through 3-methyl-1-butene, 2,2,3-trimethyloxirane and acetone through 2-methyl-2-butene, and 2-ethyl-2-methyloxirane through 2-methyl-1-butene in the vapor-phase oxidation of isopentane.

\section{Keywords}

Isopentane, Oxygenated compound, Vapor-phase oxidation, Formation pathway, Isopentene 